\title{
Social Bonds, Sexual Politics, and Political Community on the U.S. Left, 1920s-1940s ${ }^{1}$
}

\section{Kathleen A. Brown and Elizabeth Faue}

William Armistead Nelson Collier, a sometime anarchist and poet, selfprofessed free lover and political revolutionary, inhabited a world on the "lunatic fringe" of the American Left. Between the years 1908 and 1948, he traversed the legitimate and illegitimate boundaries of American radicalism. After escaping commitment to an asylum, Collier lived in several cooperative colonies Upton Sinclair's Helicon Hall, the Single Tax Colony in Fairhope, Alabama, and April Farm in Pennsylvania. He married (three times legally) and/or had sexual relationships with a number of radical women, and traveled the United States and Europe as the Johnny Appleseed of Non-Monogamy. After years of dabbling in anarchism and communism, Collier came to understand himself as a radical individualist. He sought social justice for the proletariat more in the realm of spiritual and sexual life than in material struggle. ${ }^{2}$

Bearded, crude, abrupt and fractious, Collier was hardly the model of twentieth century American radicalism. His lover, Francoise Delisle, later wrote of him, "The most smarting discovery ... was that he was only a dilettante, who remained on the outskirts of the left wing movement, an idler and loafer, flirting with it, in search of amorous affairs, and contributing nothing of value, not even a hard day's work."3 Most historians of the 20th century Left would share Delisle's disdain. Seeking to change society by changing the intimate relations on which it was built, Collier was a compatriot, they would argue, not of William Z. Foster and Ella Reeve Bloor but of cultural radicals V.F. Calverton, Floyd Dell, and Emma Goldman, figures who were and remain dubious in the eyes of the Left.

John Collier's convictions - born, as both he and his contemporaries suspected, of mental instability and personal quirkiness - offer one way of understanding the personal lives of the American Left. Reading Marx, Fourier, and Freud, Collier struggled to hammer together a personal ideology which merged social justice with free love, spiritualism, and revolutionary change. His advocacy of such ideals - at once familiar and suspect - made him an extreme illustration of the general tendency toward liberalization of sexual norms and behaviors on the Left. The success of the Bolshevik revolution, however, forced American radicals to rethink their political ideas, strategies, and institutions. The public suppression of the Left during the Red Scare required radicals to reinvent political culture and community from the resources and remnants of prewar social movements for political, social, and economic justice.

The challenge was to construct an American radical movement which captured the imagination and support of an amorphous and divided proletariat in the United States. In the post-World War I Left, roles for intellectuals, leadership 
cadres, political parties and trade union organizations were open to debate. Ideas which had absorbed at least part of pre-war left culture - sexual liberation, free love, and cultural radicalism - became suspect in view of the Left's "real" constituency of industrial workers. As Daily Worker writer H.M. Wicks wrote, "Such people are ... perverters of the theory of revolution, and their doctrines, if accepted by the working class, would only lead to the swamps of anarchism, where every person would consider his own self-expression the most important thing in the world, and his sex-life just as important as the control of industry by the working class." ${ }^{4}$ How the Left reconstituted itself in political communities, by both addressing and skirting the sex question, is one of the great untold stories of American radicalism. The questions of sex and gender, of women's equality and men's role, of place and form of families and the construction of communities were left to the vagaries and inventions of everyday life and seldom worked out in the higher realm of theory.

This essay explores some of the ways that the U.S. Left during the decades between 1919 and 1950 was sustained and enhanced by the very elements of everyday life it refused to consider important theoretically. By Left, we mean broad-based social movements oriented toward social justice in the realms of class inequality, civil rights, sex and gender relations, and antiwar activism. In the aftermath of the Bolshevik Revolution, sharp splits in the Socialist Party reconfigured the Left into new parties and organizations. The American Left soon encompassed political differences from social democracy and anarchism to Trotskyism and the Stalinism of the Communist International. We argue that, despite dynamic shifts in the range of doctrine and practice on the Left, its various factions shared in common views and behavior with regard to gender equality, the construction of political community, and sexuality.

In the context of government repression and surveillance, the Great Depression, and World War II, personal networks were vitally important to the maintenance of political commuity, especially on the Left, whose adherents were charged with creating alternative culture. We examine the roles marital and sexual unions, friendship, family, correspondence, visiting, shared celebrations, and cultural activities played in helping to forge the Left politically and to sustain its activism. We conclude by exploring the nature of sexual beliefs and practices on the Left and how the Left's sexual politics created conflict and competition, reinforced and/or subverted gender relations, and connected sexuality with political life. The ambivalence of the Popular Front Left toward private life, its reticence toward and suspicion of the sexual, and fear of alienating its broader constituency led radicals to downplay the connections between the personal and the political and to focus their efforts exclusively in the public realm of activism.

The autobiographical writings, life stories, and correspondence of men and women on the Left reveal the importance of social bonds in the creation of political consciousness and political community. While most discussion of the 
Left of the interwar and war years has focused on ideology, party history, and emergent proletarian and Popular Front cultures, we focus instead on the social constitution of left political communities and the social bases of left political culture. $^{5}$

This approach is directed to redress how differently the interwar Left has been treated from both its predecessor ("the Lyrical Left" before World War I) and its heir (the New Left of the 1960s). Historians of both these periods explored radical lives from personal vantage points and explored the linkages between personal life, sexuality, and political activism. The Popular Front Left, in contrast, has received little such attention. In the 1970s, Vivian Gornick's The Romance of American Communism made some inroads in highlighting the importance of personal life to communist activism. More recently, Judy Kaplan and Linn Shapiro's collection of oral histories, Red Diapers, brought to our attention the experience of growing up on the Left. ${ }^{6}$ Still, the dominant image of the interwar Left remains humourless, sectarian, and purely political. By documenting the sustaining personal lives of radicals, our essay reclaims the historical record and demonstrates the deep continuity in the history of the U.S. Left in the twentieth century.

Describing Josephine Herbst's experience as a reporter during the Spanish Civil War, biographer Elinor Langer stressed the centrality of relationships to understanding the communities of left writers and their politics: "What were the threads that bound together the correspondents in Spain into their tight little nest? The strands were as much private as they were political. Who was flirting with whom? Who was sleeping with whom? Who was funnier than whom? Who was louder than whom? Who was respected by whom? ... Whatever were the ties that held the correspondents together in Spain they had as much to do with the motions of the flock itself as with the turnings of the earth beneath it." Langer's questions and believe that the answers show the importance of going beyond the Left's written texts and political narratives to the culture, context, and community from which the texts emerge.

\section{THE TIES THAT BIND}

During the interwar years, the American Left reconstituted itself, as do most political communities, through intimate human bonds, such as parental and sibling ties, marriage, fictive kin, and opposite and same sex bonds as well as by political ideology. Its political activism was both fostered and supported by these dense networks of family and friends. Recruitment into communist, anarchist, or socialist cadres and socialization into the ideologies and practices of the Left - more often than not - followed these social connections. Families taught their children, and friends brought friends to rallies, discussed with them experiences in and motivations for political activism, and handed them red cards and membership forms. These "Red Diaper Babies," as children from radical families came to be called, received the political culture of the Left in their youth 


\section{Left History 7.1}

and grew up depending on its personal networks for support.

Networks often began with family of origin as a large number of left activists in the 1920s and 1930s (like their 1960s counterparts) were the children of leftist parents. Communist Dorothy Healey's Hungarian-born mother, Barbara, became a socialist in Denver, Colorado, in 1900; and Dorothy attended her first socialist meeting while "still in diapers." Dorothy's reading and discussions with her mother convinced her by the time she was twelve years old that her "life was going to be devoted to the revolution." While Dorothy learned her class politics from her mother, she was introduced to the Communist Party through her older brother, Bernard, who joined the California Young Communist League (YCL) in 1928. Fourteen year old Dorothy joined the YCL during her first meeting. Communism continued to be a family affair for Dorothy who took her three year old sister Carol Jean with her when she organized Young Pioneer groups in Oakland. ${ }^{9}$

Al Richmond was another Red Diaper Baby. Born in England of exiled Russian Jews, as a young child Richmond witnessed the 1917 Revolutions when his mother returned to Russia. After his father deserted the family, Richmond was raised by his revolutionary mother. Before he had any work experience, he fully believed that "there is a war between the classes and it is irreconcilable, the capitalist system has to be overthrown, the Russian Revolution is the trailblazing example of what is to be done." Looking back, he attributed his communism to "family background," as did others such as writer Meridel LeSueur and singer and communist Wilbur Broms. ${ }^{10}$ Actress and Communist Party activist Herta Geer also could have identified her family as the source of her political convictions. Herta was the daughter of Helen Ware Schwartz Chappell, one of the four adult children Ella Reeve Bloor brought into the Communist movement in 1919. Herta not only engaged in Depression era organizing tours with Bloor; but through Bloor, Herta had access to Left theatre groups in which she learned her trade.

Socialist Workers Party activist George Breitman, who was once described as the "best kind of revolutionary" for putting the revolution before "personal feelings and relationships," was ironically drawn into the Left by his sister. Breitman came from an apolitical working-class family in Newark, New Jersey. It was not until his father died and his older sister, Celia, left school to go to work that George was exposed to Left politics. Celia, according to his biographer, "was one of the most important influences on George as a child. She became a member of the Young Communist League and combined her babysitting responsibilities with her political ones by bringing George to meetings while he was quite young." "Sherman Labovitz was another teenager exposed to radical politics by his family. He was introduced to the Communist Party by his brother Dood and his sister-in-law, Tillie. They challenged his desire to be a rabbi, educated him in communist ideology, and encouraged him to join the YCL. ${ }^{12}$

While the complex family networks of Jewish-American Leftists are best 
documented, the importance of family background on the Left was not determined by either ethnicity or cultural background. Finnish-American Communists Ellen Pinter and Elva Lannon were the children of Industrial Workers of the World activists Isaac and Mary Lund and part of the larger Finnish radical community. ${ }^{13}$ Communist union leader Robert Schrank was raised in the 1920 s by his German-American immigrant father, a follower of Francisco Ferrer's anarcho-syndicalism. Within what Schrank described as his "extended socialist family," which included "socialists, communists, anarchists, atheists, Nature Friends, nudists, and Wobblies," he "literally was born into the socialist movement." 14 Labour organizer and later communist Eugene Dennett recalled that his Irish-Catholic parents, ardent followers of Eugene V. Debs, named him after the socialist leader. Dennett's mother, he explained, raised him to be aware of women's double burden while "working on the job and keeping house," and his father gave Dennett the time to study socialism and encouraged him to join the Communist party. ${ }^{15}$ Similarly, African American journalist Marvel Cooke recalled that the ideological groundwork for her communism was laid in her parents' race- and class-conscious socialist household; and Leftist student activist Celia Hilbert grew up in a white native-born socialist family in the Midwest. ${ }^{16}$

While not all children of the Left became politically active in the Left, many moved in that direction. Born in 1909 of Russian Jewish revolutionary parents, Peggy Dennis was raised in the Los Angeles radical Jewish community. In a childhood much like Vivian Gornick's thirty years later, ${ }^{17}$ Peggy and her sister Mini were immersed from their earliest childhood in a "belligerently atheist, internationalist, and anti-imperialist family and community." They attended Socialist Party Sunday schools and "marched on picketlines in meat strikes and milk strikes organized by a small militant women's movement, in which Mama and the aunts were very active." Their "social life revolved around fund-raising concerts for Soviet Russian famine relief, beach picnics for the Daily Worker, and dances in support of mine and textile strikes in faraway states." Raised in this family and community, Mini and Peggy adopted "the goals and hopes" of their parents. In 1922 sixteen-year-old Mini, already a YCL member, "organized the first Communist children's group in Southern California." Thirteen-year-old Peggy was the first recruit. ${ }^{18}$

Some children of the Left did not immediately choose to follow their family into radical politics. Elaine Black Yoneda was raised in the same radical community in Los Angeles as Peggy Dennis, but she took a different path to the Left. Elaine was the American-born child of working-class Russian immigrants, Jewish Workers Alliance members, who fled Czarist oppression and became charter members in the American Communist Party. Unlike many children brought up in Red households, Elaine was not included either in her parents' work or in their politics. Although she attended Socialist and Communist Party functions, she did not develop any significant class consciousness in her youth 
or in her early work experiences. Despite her family urging her to join the Young Workers League, Yoneda held back from political activism. Similarly her first husband, Edward Frances Russell, himself in rebellion from a left family, refused to join the "movement." 19

Yoneda eventually became involved in the International Labor Defense (ILD) and in Communist Party politics after witnessing the brutal attacks of the Los Angeles Red Squad on unemployed demonstrators. Her ILD work and Edward's involvement in the Trade Union Unity League were supported by living with Elaine's parents. Thus, her mother did the cooking, cleaning, sewing, and childcare, which allowed Elaine to dedicate herself to her work. After Edward and Elaine divorced in 1932, Elaine moved to San Francisco. While she continued her ILD work and lived with CP activist Karl Yoneda, Elaine's daughter, Joyce, "remained with her grandmother" for three years. ${ }^{20}$ Although her family background did not necessarily lead Elaine to radical politics, her family facilitated her political activity by providing care for her family.

Factional politics could and occasionally did undermine family loyalties and bonds, but not all families on the Left were divided. Peggy Dennis recalled that the "sharp clashes within the Socialist Party and its Jewish Arbeiter Ring fraternal order" over the Russian Revolution "tore our family apart. Aunts, uncles and friends fought bitterly ... Marriages floundered, lifetime friendships were destroyed, and our Sunday family gatherings became embittered explosions." ${ }^{21}$ Similarly, when Belle Rothman's husband, David Herbman, was expelled from the Communist Party in 1939, Belle threw him out of their house and reported it to the National Committee. ${ }^{22}$

At the same time, the risks of oppositional politics - in terms of political repression and social ostracism - were such that most activists could not survive without the encouragement of friends and family, even when politics differed. Open conflict among friends and family was not the norm, and differences were rarely irreconcilable. Even when Left factionalism took its most virulent turns, activist families controlled the damage. Dorothy Healey's family solidarity helped to create and reflect a wider definition of political solidarity and an acceptance of political differences. Max, the Soviet representative to the Young Communist International, once criticized Healey's mother, Barbara, for tolerating her son Bernard's discussion of Trotsky in her home. When Max told Barbara that he would "not come into a house where a person who is impressed by Trotsky is allowed to come," her response was unequivocal: "My dear comrade, while I have great esteem for you as a representative of the Soviet Union and of the Young Communist International, if it comes to choosing between my son and you, there is no problem in my mind. You don't ever have to come back again." Dorothy thus learned from her mother that "You could have very sharp disagreements with people, but you didn't have to break with them over those questions." 23 Similarly, communist maritime organizer Al Lannon was welcomed by his Italian-American family as "the lost 
son returning home." Under an unspoken agreement that Lannon would not criticize his siblings' Catholicism nor would they attack his politics, family members maintained their loyalty to each other. Even when two of Lannon's brothers failed to receive promotion in the armed services due to Lannon's politics, the brothers "saw no reason to resent their brother." His birth family continued to be "a place of respite."24

Political communities withstood opposition and repression precisely because they were formed around and helped to foster social ties, including those of sexual and emotional intimacy. Marriage and long-term sexual relationships between same-sex and opposite-sex partners were the foremost of these bonds. Whether short-term or lifelong, intimate relationships often supported the political activism of individuals as well as creating a context for family and community life on the Left. At the same time, relationships are shaped by the gender and sexual norms within communities. Due to the intense pressures of oppositional politics and the sexual and gender ideology of its adherents, the Left could both foster and sometimes threaten sexual and marital unions.

Ann Kimmage's autobiography, An Un-American Childhood, reveals the politically complex dynamics within the seemingly traditional marriage of her parents, Abraham and Belle (Shulman) Chapman. Writing of her mother's quest for political self-determination, Kimmage saw it as linked to her mother's resistance to traditional gender ideology:

As a female in her father's Orthodox home [Belle] had no voice or power, but in the communist movement she could challenge the enemy with her sharp intellect and organize to institute change. Belle frequently commented that women in an Orthodox home were limited to raising the children and running the household so that men would be free to commune with God. ${ }^{25}$

In 1934, Belle Shulman met and married Abe Chapman, "a self-taught Marxist." According to Kimmage, marrying Abe "liberated" Belle:

to establish an independent and radically new life. After their marriage, Abe and Belle returned to the United States and settled in Chicago ... where most of his family lived. Here they met people in the communist movement who introduced them to a political network through which they could channel their energy and shape their worldview. ${ }^{26}$

Although Kimmage's mother was "a traditional wife," she was also "a radical non-conformist." Belle cooked, ran the household, typed for her husband, and cared for Ann and her sister. According to Kimmage, however, her mother was "a spiritual companion and equal" to her father. Employed outside the home, Belle Chapman shared and contributed to her husband's writing and political work. In Kimmage's analysis:

In their long-lasting partnership Abe and Belle worked one mind against the other, gaining from their different approaches. They were bound to each other and to their commitment to the communist cause, one inseparable from the 


\section{Left History 7.1}

other. Down to earth in her judgment, my astute mother saved our family from political dangers my father could not detect with the same sharpness and speed.

My father was a dreamer, theoretician, and visionary. He needed my mother to balance the scope of his dreams and to keep us alive. ${ }^{27}$

Certainly not all marriages among radicals offered such balance, but companionate and egalitarian marriages were made possible in the Old Left by a political ideology that at least recognized the woman question. For many activists, it was a question of negotiating the line between radical politics and its imaginative possibilities for changing personal lives and their own predilictions in intimate relationships. Sexual emancipation and sexual equality did not often go hand in hand, and the fit between personal lives and political beliefs, even where there were strong feminist inclinations on the Left, was uneven. As cultural critic Constance Coiner discovered when she explored the lives of writers Meridel LeSueur and Tillie Olsen, even strong, creative women activists could reproduce patriarchal and/or sexist relationships with the men in their lives. ${ }^{28}$ As neophyte communist activist Basha de Ward explained in a letter to Harvey O'Connor, evidence that her husband, Vern, considered himself a communist was to be seen in "the fact that as I am typing this he is in the kitchen washing dishes and singing "Tis the final conflict." 29 Still, while the Left did not have a coherent or consistent stand on sexual equality, the oppositional culture of the Left created new possibilities for women's involvement, and such politics changed the relationship both between sexual partners and in families.

In practice, if not in expressed theory, couples embraced the belief that common work enhanced relationships. As unionist Powers Hapgood wrote to anarchist and labour organizer, Rose Pesotta, "we are more than lovers, sweetheart. We are comrades in the anti-capitalist struggle." Co-authorship or cooperative authorship appears to have been common among Leftists. Others such as Emma Goldman and Alexander Berkman, Margaret Collingwood and Stanley Nowak, Farrell Dobbs and Marvel Scholl created partnerships of shared cultural labour. ${ }^{30}$ Marriages and other intimate unions frequently went beyond the sharing of household arrangements to underwrite cooperative work in community and labour organizing as well as political and cultural work. Grace Hutchins and Anna Rochester, co-founders of the Labor Research Association, had a long-term relationship which allowed them each to write and do cultural work. Similarly, CIO organizer Lucy Randolph Mason drew support from Margaret Fisher. Grace Carlson and Vincent Dunne cooperated in labour and political work; Maud and Sylvanus Stockwell supported each other's organizing in suffrage, peace, and socialist organizing. ${ }^{31}$

At times, radical relationships took the form not of direct support or common work but of mutual autonomy and independence, which allowed domestic partners to pursue individual concerns. While Jacob Hardman engaged in Communist Party politics in New York City, his wife, Hannah, took their daughter, Yvette, with her to California, where Hannah wrote and 
translated children's stories. The arrangement allowed them to pursue their ambitions while providing emotional support. Similarly, for several years John Herrmann's relationship with Josephine Herbst allowed him to engage in CP farm organizing while Josephine wrote. Radicals Harvey O'Connor and Jessie Lloyd pursued writing and organizing careers that were punctuated by long periods of separation and passionate reunions. ${ }^{32}$

\section{MORE THAN LOVERS: COMRADES}

One of the common, but largely unexamined, aspects of Left autobiographies is the reality of "camaraderie, the being united in not only a cause but close friendships." 33 Communist Party leader Junius Scales was fully recruited into the $\mathrm{CP}$ in 1939 by Bart Logan, then CP district organizer for the Carolinas. Looking for someone to write and distribute a leaflet for a textile strike, Bart introduced Scales to organizing. Scales was "enraptured by his genuineness, his warmth, his humor, and his profound sincerity." Upon meeting Bart's wife, Belle, and daughter Elaine, Scales "at once ... felt the warmest sympathy and affection" for the family. He took to bringing food by the Logans "two or three times a week, or oftener" and having dinner with them. ${ }^{34}$ Like many other organizers, Scales and the Logans were mutually dependent on each other for resources. The intertwining of personal and party life made such connections emotionally important as well.

Similarly, Dorothy Healey recalled the importance of friendships within the YCL: "I grew particularly close to Minnie Carson, who was Peggy Dennis's sister, and to Minnie's husband, Al Bock, who were both about ten years older than I was. They lived on Twin Peaks in San Francisco and I would go over there every moment I could to be with them." And when Minnie was struck by a police tear gas canister, which "cut her check wide open" during a strike, it was Dorothy who rushed her to a hospital for stitches. Back in San Francisco, the two women shared birth control methods and abortionists, when the devices did not work. ${ }^{35}$

Ann Kimmage recalled life in her Queens, New York, home prior to the family's underground flight from the U.S. in 1950: "[The] cramped rooms always accommodated the extensive circle of my parents' friends and comrades ... 'Family' took on a broader meaning, involving friendships that were international and based on political (rather than religious or ethnic) solidarity." ${ }^{36}$ Like many adherents and children of the Left, Kimmage repeatedly employed the language of family to describe her parents' leftist friends: "I was not only a child in the family I was born into; I was simultaneously brought up by the communist family my parents belonged to." She envisioned the hearth as the center of her extended political family: "In the United States my parents' friends made themselves at home, helping out with the cooking without interrupting the flow of dialogue. During meals, the conversation switched back and forth from in-depth political arguments to discussions of family and personal 
relationships." 37

While autobiographies and biographies of ex-CPers frequently emphasize the sacrifice of friends due to Party factionalism, they frequently overlook the continuation of friendships across party lines, even after political allegiances have shifted. Socialist Party activists Clara and Bill Hilbert maintained their close relationship with the ex-Socialist and then Communist Party organizer, Ella Reeve Bloor, and her family throughout the 1920s. Despite their political differences, the Hilberts valued the warm, supportive, personal ties with both Bloor and her son, Dick Reeve. ${ }^{38}$ The Hilberts' home in Dayton, Ohio, was, Ella reminded Dick, "really your home." 39 The youngest Hilbert child, Dorothy, decided to attend the University of California, Berkeley, because it allowed her to live with Dick and his wife Celia ${ }^{40}$ And when Bloor was arrested for her communist activism on a sedition charge in 1922, her old friend, Socialist Party member and United Mine Worker lawyer, Caroline Lowe, defended her. Four years later, their friendship was still vibrant. When Bloor was in town, she enjoyed an evening of socializing with Lowe and the socialist publishers Emanuel and Anna Marcet Julius-Haldeman. ${ }^{41}$

Rather than politics dictating friendships, friendships could and did override politics. Explaining to Dick that two of her long time leftist actor friends had stopped corresponding with her, Bloor wrote: "for some strange inexplicable reason they've crossed me off their books .... However, I've gotten over that 'hurt' as I have never lost a real friend and I believe they are real[,] and will some day regret any pettiness they may have had toward me in order to keep some other 'transitory' friends." ${ }^{2}$ Bloor was not alone in the Left for placing friendships before politics. The correspondence between Mark Litchman, Emanuel Slater, and Len De Caux specifically addressed the need for people on the Left to create and maintain personal and political alliances among the $\mathrm{CP}$, the IWW, and the SP. ${ }^{43}$ After calling his Socialist Party friend, Eugene Belmont, a "damn fool" for the "ruthless" manner in which he broke off their friendship, Communist Mark Litchman expressed the hope that they could "still keep up our friendship, even if we do get under each other's hides once in a while."44 In like fashion, independent Leftist Harvey O'Connor strove to maintain friendships and working relationships. As he explained to a $\mathrm{CP}$ member, "My position toward the party and its work is clear enough, I think. I don't want these personalities interfering with our relationships. Can't we clear them out of the way?"45

Why some Leftists were able to maintain friendships and family relations despite political differences and others could not is perhaps impossible to discern. It might be attributed to differences in personalities, individual commitments to create and maintain community ties, and in varying beliefs about the importance of striving toward an ideal even in the way one lived one's everyday life. For the Swedish-American socialist Henry Bengston, ending friendships over political disagreements was "unthinkable." Like many other 
radical organizations in 1919, Bengston's Scandinavian Socialist Federation was divided over whether to remain in the Socialist Party or to move to the new Communist Party. As a member of the losing faction, Bengston watched as the organization he helped create moved into the communist Left and slowly disintegrated. Despite the acrimonious nature of the split and the loss of his own party job, Bengston recalled, "the differences of opinion expressed within the Federation did not produce any personal animosities between the followers of both camps." Recounting his friendships with $\mathrm{CP}$ members and social democrats, Bengston stated that "I still had old friends in the organization, and even if our political views were miles apart, we never broke off our personal ties. It was simply unthinkable for me to allow political issues to raise walls in my friendship[s] ..., but any thought of political compromise was out of the question." 46

In contrast, Trotskyist Berney Mayes was perfectly willing to realign his personal relationships to coincide with his political position. "Yesterday's friends," he explained, "became strangers and antagonists over night." Perhaps one of the reasons that Trotskyists such as Mayes and their CP counterparts might have been more inclined to disavow their previous friendships was the increasingly virulent political conflicts between them. Mayes recalled that, by the early 1930s, he believed it was the CP, not the capitalists, who stood in the way of revolution: "My bitterness to the Stalinists had grown to the point that I considered them the chief obstacle that would have to be removed if the working class was ever to have a chance to take over political power." ${ }^{27}$ Thus Trotskyist Sidney Hook and his former wife, Communist party member Carrie Katz Hook, could remain friends until Sidney's "increasingly bitter split with the Party caused their remaining ties to dissolve." $" 48$

Bonds of friendship may have been put to the test by rętreats from Left political activism, but they were seldom destroyed. When he left the Communist Party in the 1950s, Sam Darcy was penniless, with family and parents to support. Rather than rejecting him, his old Party friends gave him an "amazing amount of close sympathy." They helped him find work, put his boy through college, and helped with the family's other needs. ${ }^{49}$ Similarly, when Charles Shipman needed help, he turned to Liston Oak, his "most trusted friend." Shipman explained: "Liston and I had been Communists together, disenchanted together, expelled together, publicly denounced together." When Shipman and his spouse decided to go into hiding from the FBI, they called Liston who, on a moment's notice, "undertook to close the house, settle the lease, dispose of the books and furniture, take charge of our dog, do something about the cat and five newborn kittens," sell the car, and fix things with one of the Shipman relatives. ${ }^{50}$

Left friendships may have been born, as Charles Shipman argued, out of "a heady feeling of comradeship born of the conviction that our lives were in tune with history"; but when lives took divergent political courses, friendships could and did remain. Shipman recruited Girolamo (Nemo) and Juanita Piccoli into 


\section{Left History 7.1}

the Communist Party and developed "a rare personal sympathy" with them. At first when Shipman left the Party in 1937, the Piccolis, whom Shipman described as "practically family," acrimoniously broke with him. Charles believed that the friendship stood no chance of being reestablished unless the Piccoli's "abandoned communism." But only five years after their break, Juanita and Nemo reestablished their connection. "The personal had bested the political," Shipman recalled, "with 'certain subjects' out of bounds, we were friends again." The friendship won out even after vicious political disputes were ended, stilled by Nemo's exclamation that, "Well, we love each other anyway!"5I

Even breaking off sexual relations was not necessarily a reason to terminate friendships forged through political activism. For nearly thirty years after they dissolved their marriage, socialist Miriam deFord and anarchist John Collier kept up an intense exchange of letters that debated political and sexual beliefs, challenged each other's patience, and traded on each other's knowledge of friendship networks from coast to coast. Collier wrote deFord repeatedly about his new intellectual discoveries; they exchanged books and traded creative writing. Collier called deFord a "damned monogamous squaw" while smarting under her new marital fidelity; but when Miriam was ill, her husband Maynard wrote to Collier for financial help and he sent it. And when Maynard had heart problems, Miriam sought emotional and financial support from her old lover Collier, recalling that she had similarly bolstered him. ${ }^{52}$

Friends frequently played an important role in recruiting others into radical movements. While both John Abt and his sister, Marion Bachrach, were formally and separately recruited into the Communist Party, the seeds of their recruitment were sown during their long-term friendship with communists Closson and Millie Gilbert. Spending her summers in a small cottage in Vermont, Marion Bachrach lived next door to the Gilberts' potato farm. From 1928 to 1932, talking with the Gilberts about the Sacco and Vanzetti case and visiting them when they hosted Sacco's son Dante, Marion began to sense "how the self can grow through social commitment." 53 Through their friendships with the Gilberts, John and Marion came to understand and sympathize with the Communist movement. These sympathies influenced Marion and John to join the Party in 1934, when Ella Reeve Bloor's son, Hal Ware, asked them. ${ }^{54}$

\section{SUSTAINING POLITICAL ACTIVISM AND SOLIDARITY ON THE LEFT}

For organizers, radical journalists, or others on the Left who were separated from their home communities, correspondence served as an important way of maintaining bonds and sustaining political activism. While it is easy for political historians to ignore or skip over letters which deal with what might appear to be gossip or "simply" family minutia, in fact correspondence among left activists is permeated with information about how political lives are lived and how they intersect with "personal" experience. Such letters reveal the intimate connections, social resources, and personal bonds which constituted political 
communities of the Left and made possible individual activism. Harvey O'Connor's correspondence is a case in point. O'Connor came of age politically in the Seattle/Tacoma area during the First World War and the Seattle General Strike of 1919. In the early 1920 s, as radical friends moved out of the area, O'Connor maintained his social ties and built new ones through extensive letterwriting. His correspondence began in 1920 and continued throughout his life. The members of Harvey O'Connor's circle included Art Shields, Hays Jones, and Joe Pass. Their letters are a bridge to understanding the history of the Federated Press, the IWW, independent radicalism, and the Communist Party through World War II, oening a window into left political communities.

As the men of Harvey O'Connor's circle matured and created partnerships and friendships, their letters documented the creation of radical community among wives and friends and across generation and geography illustrating the importance of social networks as well as family relatinships. One example is Harvey's friendship with Kate Sadler, who played a significant role in the preWorld War I Washington state socialist party and the anti-war movement. Upon receiving a Noel card in 1937 from Harvey and Jessie, Kate wrote them about the politics and personalities of the Seattle Left. She had been corresponding with Minnie Parks and Hulet Wells and sent Harvey Wells' address, implying that Wells could use some economic help. Sadler continued, "I had a nice letter from Greta Drumm, Bristol Penna, she sent a poem \& a story she had written with some snapshots of her own \& Phyllis' boys. So all in all I have been remembered lovingly by many many friends $\&$ comrades it brings a glow to my heart, for after all Harvey, there was nothing outstanding in any contribution I may have made, it was but a part of group activity with none striving for this thing known as leadership." 55

Whether radicals were on the road organizing and writing or at home doing political work, they maintained their social connections and sustained their activism through personal letters. The need for such correspondence grew proportionately to their sense of isolation and the constraints on other forms of contact. Chief among such obstacles to their accustomed community was geographic distance (whether cross-country or international travel), re-location in a new community, or imprisonment. Art Shields' letters to Harvey O'Connor were filled with developments in the lives of friends from Seattle, the politics of the Daily Worker, and new people in labour and on the Left. Knowing where one's friends were proved invaluable to political work. If an organizer needed information, housing, or help during a campaign, his/her circle of friends provided local contacts and resources. But the political networks which Art described were more than utilitarian. Personal friendships shielded political activists from local opposition, softened disappointments and celebrated victories, and sustained political life through joy and laughter. Art Shields and his partner Esther Lowell were working in the Eastern Bureau of the Federated Press when Art wrote to Harvey: "We visited Gene Lyons last night, taking 


\section{Left History 7.1}

Ralph Winstead along. Opertz was there and a lot of other folks and there was a merry time with much dancing and chatter." ${ }^{.66}$ Sharing experiences by mail was another way of integrating old friends into one's new political community.

When they were relocated to an internment camp during World War II, Elaine Black and Karl Yoneda found their only link with their larger world was through the "extensive correspondence with friends outside." 57 As her biographer remarked, "Elaine and Karl were fortunate in having moral and financial support from her parents and relatives as well as scores of friends whose letters and gifts helped ease the burdens of Manzanar." ${ }^{8}$ The Yonedas' particular situation - internment - was unusual among communist activists; but leftists who volunteered for or were drafted into the armed forces during the Second World War demonstrated similar needs for contact with the radical communities they left behind. Once in the service, they experienced separation anxieties, desires for news from comrades and comfort from partners at home, and fears about being posted on the basis of their radical activities. The correspondence between Army private Fred Fine, who had been a YCL leader, and his wife Doris Fine, reveals the desperation for contact with like-minded people that Fine and others felt..$^{59}$

Grace Carlson, a Socialist Workers' Party leader, used correspondence to develop her personal as well as political relationships with comrades Farrell Dobbs and J.P. (Jim) Cannon. In doing so, she built upon already dense networks of friends and family, including her sister Dorothy, who also was an activist, and Rose Karsner, Cannon's partner. Some of the letters reverberate with humor, as Jim Cannon did when Grace (and her partner Ray Dunne) sent him a silk bathrobe:

The receipt of this present marks a new stage in my career. It is the very first silk bathrobe I ever had in my life. But I must say it becomes me. After I had it on and found that it fitted so well and set off my Senatorial figure to such good advantage, I felt a strong desire to wear it all the time like a Roman Senator in his toga. If it weren't for my 'conservatism' in matters of public custom, dress, morals, etc., I would go down the streets one of these incoming Spring days dressed up in my fancy bathrobe and agitating for a revolution against the custom of wearing coats and pants and other capitalist forms of dress. ${ }^{60}$

When Carlson was convicted under the Smith Act and sent to Alderson Federal Penitentiary for Women, letters, especially from close women friends at home during the war, became her lifeline to the outside world and connecting link to her political life. When she left the prison, the Socialist Workers' Party threw a banquet in the honor of Carlson and the other 17 labour case defendants; but the toast offered her by sister Dorothy and friend Ben, who practiced "The Rose of Tralee" for her, might have carried equal weight. ${ }^{61}$

The internal dynamics of social gatherings, speaking tours, political dinners, and holidays played an important role in creating solidarity on the left. 
Dorothy Healey recounted the happy times in her marriage with Lou Sherman .when Ben Dobbs (not a Party member then) "and his then wife Lollie came over every weekend for wild sessions of a card game called Long Beach rummy." 62 When Clifford Odets came to visit Chapel Hill, Junius Scales recounted, almost every evening was spent having dinner, consuming "cases of beer," and engaging in "conversation that seemed profound at the time." 63 Drinking, dining, and arguing over poetry, music, literature, and communism was usual fare for many denizens of the Left. When Joe Kuzma was arrested for violation of the Smith Act, he was leaving a house "where he had stayed late for tea, cookies and a game of cribbage after a guest appearance at a party club meeting." 64 Ann Kimmage recalled that, "It was not uncommon for me to come home from school to find my mother preparing dinner while engrossed in conversation with a friend sitting at the kitchen table. They discussed politics, personal problems, relationships, love, family, and separation while the soup got made and the potatoes peeled." 65

Charles Shipman wrote of his experiences living in New York City with Liston Oak and Margaret Larkin in the late 1920s. He wrote that their "hospitality, attractiveness, and verve made their place a sort of East Thirteenth Street salon for friends and friends of friends. Arriving home late from a night of one harried meeting after another ... I might find Jessica Smith, Genevieve Taggert, Jimmy Harris, Alex Gomberg, Adelaide Schulkind, or other guests in the living room. I usually joined the gathering." Moving from Liston's apartment to his own in 1930, Shipman himself "did a bit of entertaining, most of it with the old Chicago gang: Bill and Marguerite Dunne, Wally and Rose Carmon, Fred Ellis, and Thurber, when he was in town." 66

Connections among friends, family, and comrades served many purposes. They provided a sense of community and common endeavour, and they filled the need for emotional and material support. When Hays Jones moved in the late 1930s from the east coast to Chicago, he was cut loose from his circle of intimate friends. Following Art Shields' visit to Jessie Lloyd O'Connor in Pittsburgh, Jessie wrote Harvey: "Art says Esther stopped off to see Hays on her way out and he looks really bad, and when she took him out for a meal he ate more starvaceously [sic] than she'd ever seen him. Maybe we ought to move to Chicago after all. Somebody ought to let him come over and cook an Italian meal. But Art says friends are pulling wires to try to get him transferred back to NY." ${ }^{67}$ After a visit with Rose Hanna, Esther Lowell wrote a warning note to Harvey O'Connor saying that Rose reported he looked tired. Esther chided Harvey, "Don't overdo. You've been turning out good service lately but don't break down at it." 68

Bonds of friendship among Leftists often led to shared living arrangements - for both financial reasons and from intense personal attachments and desires for community. In the late 1930s, John Abt and Jessica Smith, who were married but living apart, rented a house on Long Island. They arranged to share the house 


\section{Left History 7.1}

with friends Mattie and Phyllis Silverman. Abt and Smith joined them on weekends. Weekends at the house frequently included J. (Pete) Peters and his wife Anne, Nat and Anna Witt, and Harry and Vera Freeman. For Abt and Smith, these weekends set the pattern for their married life. Living in Queens in 1940, the couple's "Saturday nights were invariably spent in the company of the Peterses and the Silvermans, and often included the Witts and Freemans, for roast beef, drinks, and poker." 69

In $1938 \mathrm{Abt}$ and Smith purchased a small cabin in rural Kent, Connecticut, which became a retreat and meeting place for their "dearest friends and coworkers" for thirty-five years. ${ }^{70}$ As the cold war took off and tensions within the Left increased, Abt "was drawn even closer to" his "family and friends." For John and Jessica, the Berkshire cabin became "ever more a retreat for us from the corruption gripping the country's political culture." While the intent of the Communist witch hunts of the cold war was to divide and disperse the Left, the effect on John was centripetal. Rather than abandoning their community, the Abts and their closest friends "became an extended family." 11 "Fictive" and "real" kin of John and Jessica gathered in their Kent house. The family visitors included John's mother, his sister (Marion Bachrach), along with Maxine Wood, who was Marion's yearly vacation-companion and sometimes housemate. Jessica's family visitors included her ex-mother-in-law (Ella Reeve "Mother" Bloor), step-daughter (Judy) and her family, and son (David). Old friends continued to flock to the house, and new friends made through John's participation in the Progressive Party widened the social and community circle. Frequent visitors included Beanie and Lillian Baldwin, Lou and Dottie Burnham, George Murphy and Thelma Dale, Arnold and Aurelia Johnson, and Ruth Jett. Depending on the guests and the circumstances, they "rehashed the successes and foibles of the IPP and worr[ied] over the friends and comrades of the Party who were underground." Most of these friends and family used the Kent home as their own family vacation $\mathrm{r}^{\prime}$ reat. ${ }^{72}$

Shared holidays became central to mantenance of political life among Left activists. Writing of her "very dear personal" friendship with Harvey and Jessie Lloyd O'Connor, Ann Branden explained that "for almost 20 years, Carl and I and our children spent a month each summer in a little cottage on the property Harvey and Jessie owned on a beautiful rock? roast at Little Compton, R.I. Those sojourns were probably what enabled us to stay in the social-justice movement, and we were only two of many who went there to recharge tired batteries. The O'Connors shared their beautiful hom: with assorted radicals and activists, who peopled the place in droves every summer." 73 Another exFederated Pre's associate, Horace B. Davis, held open house, inviting Harve * and Hays Jones to stay with him in his house at Sandwich, Massachusetts, where a couple was already visiting and friends were expected every weekend. ${ }^{74}$ Federated Press correspondent Tom O'Connor helped ease the stress of some of the leaders of the New Bedford Textile stril $s$ in 1928 by taking Hollace 
Ransdell, Carl Ross, and Ann Craton to his "shack in the country" for a couple of days. Tom reported to Harvey that the activists "reveled in it" and repeated his invitation to Harvey and his then-wife Blanche to come up. ${ }^{75}$

Frequently, Left families and friends offered more than emotional support for each other. They also operated as fictive kin networks, helping to raise each others' children and providing group housing. Sherman and Pauline Labovitz lived in the "first-floor apartment of a house owned by Pauline's parents," who were also activists. "Two other Communist Party activists and their three children" rented the top floor apartment. ${ }^{76}$ Stanley Nowak and Margaret Collingwood began their marriage by living with her parents and sharing expenses while Stanley organized for the UAW. When they needed an apartment in Stanley's district the year he ran for state legislature, they moved into an upper flat with union friends Tony and Irene Marinovitch. It was an arrangement which lasted for years, while Margaret and Stanley lived part-time in Lansing. ${ }^{77}$

The correspondence between Hays [Jaze] Jones and Harvey O'Connor illustrates the physical and emotional importance of friendships, fictive family, and support networks. Leaving Seattle in 1921, Jones hoboed east to link up with Harvey's friends. Jaze landed in Chicago where he stayed and wrote "propaganda pieces" while staying with Art Young. ${ }^{78}$ From Chicago, Jones went to New York where he arrived with only the clothes on his back. After a meal, a bath, and some sleep, he set out to see some of the young New York radicals. He was at a serious disadvantage in that the only clothes he had were his hoboeing duds. Yet, as he explained to Harvey, "I met two fellows, one through Art Shields, the other thru the one, and acquired a suit of clothes and a cap." Wearing his new clothes, Jones set out on "an investigation tour" to explore life in N.Y.79

Within four months, through Art's contacts, Jaze acquired a new "family circle" and address: "We are Ruby and Morris and Jaze. We are now occupying an apartment together although at present $I$ have resigned my bed to a sick woman, a newly acquired friend of the gang, for a few days. There are advantages in the situation from my point of view. First of all it diminishes the rent, and offers good company." 80 In April of 1922, Jones wrote that he was going to venture out on the road again. He did not have much money, he told Harvey; but as long as Jones could hobo to Cleveland he could "seek a little free food ar 1 shelter from some of Morris' friends there." While Jones often reveled in the role of a unattached Wobbly, he was surprised by the depth of the personal connections he had made in New York: "Really the solicitude manifested by my friends is disconcerting. Of course I would not turn it down, far from it, but it was so unexpected and so illy waranted [sic] by my unfaithfulness to most of them that it took me off my guard." 81

In contrast to Hays Jones, CP organizer Ella Reeve "Mother" Bloor had a quarter-century of organizing experience when, in 1925, she was transferred from California to Pennsylvania to organize mine workers. Bloor readily acknowledged to her daughter that, while things were going all right with her 
work, her "greatest trouble" lay in "the lack of congenial friends." Later that same month, she wrote her son Dick that "friends, old ones, are gradually rallying around." 82 Bloor was fully cognizant of the need to build broad networks, as she depended upon her friends and fictive kin for emotional sustenance and practical help in organizing. She often relied on friends for winter coats, car and train fare, intellectual conversations, and social and political contacts. ${ }^{83} \mathrm{Just}$ as her friendship network supported her in sickness and in health, so too did she try to bring activists into the network so that they could participate as well. When her son Hal was in the USSR and his wife Jessica Smith was in the United States, Bloor drew Jessica into the family's social and extended kinship circle. Upon Hal's death, Bloor made special efforts to include Jessica in her community. When a few years later Hope Hale Davis' husband died, Jessica Smith did for Davis what Bloor had done for Smith. Smith formed a friendship with Davis and brought her into Bloor's extended family. ${ }^{84}$

When communist writer Claude McKay decided to go to the USSR in 1922, he sent out requests for money to his friends in the NAACP, Black literary circles, and to his friends from the Liberator. His close comrade Crystal Eastman appealed to her friends, and between "liberals, radicals, and bohemians" enough money was raised for McKay's journey. Twice while in Europe in the early 1920s, he fell deathly ill (first syphilis, then influenza). He was cared for by American radicals - first a Liberator artist friend, then by Louise Bryant Bullitt and Josephine Bennett of Brookwood Labor College. ${ }^{85}$ Similarly, while his NAACP contacts failed McKay, he maintained close friendships with Crystal and Max Eastman, who helped finance him and provided sought-after editorial advice.

Writing in his memoirs about the Communist Party, Max Bedacht described the consequences of his having moved from Chicago to Philadelphia. While it kept him close enough to continue his work, moving was complicated. As Bedacht later recalled, the situation was made more precarious by a conviction for criminal syndicalism: "My court conviction in Chicago was sure to land me in a penitentiary. We had to try to secure the existence of the family in that emergency. The first and foremost problem was to get secure living quarters. To this end, I, together with two other comrades, Alfred Wagenknecht, and Louis Katterfeld, who were in the same boat with me, made arrangements to secure a common home for our families." After they pooled their money, the families bought a farm in Connecticut, "a large farmhouse [which] offered a roof over the heads of the numerous members of the combined families." 86

Such shared housing and child care arrangements continued in the Depression among the irregularly employed and politically committed. Phyllis Charter and Bob Robbins, Esther Lowell explained to Harvey O'Connor, "live in our dom-ground floor. Welfare (county) was going to pay rent but came through only once. Supplies about $\$ 3.50$ of groceries a week, plus 2 quarts milk a day and occasionally on demand will pay something on gas and light." Money 
was so tight, "The landlord threaten[ed] eviction." While Bob Robbins did "occasional work in the World Telegram printshop" and in a new league for unemployed printers, "Phyl [was] busy with work in Yonkers, making signs for the Center, drawing up letters for Unemployed Council, besides running her house and tending two kids. She gets lunch for Allen and me - we share with her family on it." 87

After being fired from her job with the Office of the Coordinator of Information in 1942, Josephine Herbst needed a place to stay. Dorothy Farrell, the ex-wife of her old friend Jim Farrell, invited Josie to live in her house in Chicago. According to her biographer, "It was exactly what Josie needed. Dorothy was living in the midst of a bustling, good-natured, and unconventional adult household into which the addition of another lively character was the most welcome thing in the world .... [I]t was a house which attracted the most unlikely, eccentric, and incompatible personalities in the neighborhood and wove them into a temporary whole. In its warmth and casualness, in a family atmosphere that kindled memories of her own childhood, Josie relaxed." The finances of the house were such that Josie didn't even have to work; after her recovery, however, she found a new job, did volunteer work, and renewed old friendships. ${ }^{88}$

Factory worker and YCL activist Doris Fine, who relied on her own earnings while her husband's army paycheck went to pay his back debts, explained to him that financially she was surviving. She and fellow YCL leader Adeline "pooled our financial resources and we've been getting along fine." The cooperative nature of their finances included shared housing. ${ }^{89}$ When Doris found that, even with shared housing, she could not make financial ends meet on her wages of fifteen dollar a week, she turned to aid from other friends. Doris explained to Fred: "I have accepted Anne's long-standing invitation to eat at her house everyday. At least one meal - it will help me considerably."90

Correspondence among those on the Left is filled with requests for visits. Joshua Lieberman working at a New York Pioneer Youth camp wrote to thank Harvey for writing a press release for the camp. He asked Harvey to come and visit. If the lure of Joshua's company was not enough, he offered the chance for Harvey to reunite with old friends: "This might act as an additional inducement: Alicia Rosenbaum, formerly of Seattle, is typing this letter and will stay here all summer as the camp secretary. Another person that I understand you know is Ursulla Pass, and her son Dwight, also of Seattle, who will be here, too."91 Maintaining old friendships through visits was important, especially if one lived in an area where left politics were not welcomed. Left activist Carl Brannin, who knew Harvey from the Washington state Left, frequently requested that he and "Mrs O'Connor" visit the Brannin family at an isolated logging community on the Washington coast and later in Dallas, Texas. Some times visits or requests for visits were purely social; at other times, they were about using contacts to find jobs and housing. ${ }^{92}$ 


\section{Left History 7.1}

Both formally and informally, those on the Left shared in rituals and celebrations around holidays, marriages, births, and funerals. While some on the Left ignored religious holidays, others used them as a time to celebrate family and community. Labour journalist and ex-IWW activist Len De Caux combined his radical politics with holiday spirit in writing Harvey O'Connor: "This is a Christmas letter bearing the greeting of Kathleen and Donal as well as of their parents and wishing the both of you more happiness than any other of the plutes who live on Riverside Drive! I only wish that you could be here to enjoy the children's Christmas with us." 93 After bringing home their new baby, Jack and Alma Lever sent Harvey O'Connor news of the safe delivery and the healthy child. They wrote: "Sonny Danny looks fine and is quite a gentleman machinist about keeping noiseless. He looks good to yours truely and we'd be glad to have you out to see him Saturday for dinner ... If you can come earlier so much the better." Similarly, Jessica Smith and John Abt hosted huge Thanksgiving parties at their Kent house. "Besides Marion, mother, David, Judy and Daniel and the kids, and the Peterses before their deportation, we'd import our Jackson Heights poker regulars - the Silvermans, the Kramers, the Witts, Gerhardt Eisler if he was available." 94 While Earl Browder served a prison sentence for passport violations, Communist Party friends extended their friendships to Earl's wife, Raissa, and their children into a supportive community. Bob and Lydia Minor, Ella Reeve Bloor, Elizabeth Gurley Flynn, Charlotte Anita Whitney, and Anna Rochester and Grace Hutchins reached out to visit with, send gifts to, and share birthdays, holidays, and cultural events with Raissa and the children. Raissa spent one Christmas day with Bob and Lydia Minor and an Easter with other party members. ${ }^{95}$

Cultural activities helped to cement Left political and communal bonds. Participation in radical meetings, labour schools, and community picnics helped create bonds as did theatre troups, reading circles, and clubs like Chicago's Dill Pickle Club. While living in Chicago in the early 1920s, Shipman engaged in "recreation" at movies, picnics, "Sunday morning confabs at the Radical Book Shop, Ben Hecht evenings at Dill Pickles, and a certain amount of carousing with Prohibition gin or mustikha in other comrades' homes." ${ }^{96}$ Radical theatre provided another social and cultural outlet. Communist activist Nan Havel, to use only one example, played a role in a production of Fanny Bixby Spencer's Jazz as Patriotism, an anti-war play. Workers' theatres across the country performed productions of Left dramas and comedies and contributed to a growing body of proletarian and Popular Front literature. ${ }^{97}$ Cultural activities and social events might be planned at the spur of the moment. Jessie Lloyd O'Connor recounted one such happy evening she spent at a "meeting":

Saturday night Hugh Wing and Day Krolick invited me to their house to confer with Lee and his Italian artist gal friend and an artist gal friend of Hugh's about the art exhibit for the League Congress here in November. When 1 got there Nell was saying, "where are we going to dance? I just got a double pay check." 
What welcome words. But as usual the guys didn't have any money, and didn't want to keep their coats on (it was sticky hot) so we all went to her place - a very large room - and did the Virginia reel, foxtrot, tango, schottische, polka and waltz. And Kermesse Heroique!

"That," she wrote, "is my idea of a nice business meeting."98 At other times, members of left circles organized specific cultural outings. Junius Scales' organizing trips to Memphis included being taken by the local CP head "to a memorable recital by the mezzo-soprano Jennie Tourel, and there had also been some chances for socializing with the other comrades." 99

\section{THE SEXUAL POLITICS OF LEFT POLITICAL COMMUNITIES}

If relationships were the building blocks of political community, there were times when they might pull friends and families apart. This was particularly true where sexual relationships were involved. At the same time, sex could serve as a method of sustaining solidarity and activism on the Left. Dorothy Healey argued that one of the reasons for the frequent use of sex was to create community: "I had often slept with men," she recalled, "not because I gave a damn about them but because it was the easiest way to establish friendships." She added, "and because it reassured me of my attractiveness." 100 The practice of using sexual connections to foster political ones may have been employed by both men and women activists, especially those who continually moved into new areas and had to re-create relationships to facilitate their work. Jessie Lloyd told her new lover, Harvey O'Connor, that he could sleep with the women he was going out to interview for his work with the Federated Press, "if it would help him in his business." 101 Dorothy Healey related one dark side of sexual intimacy in the Communist Party:

There was one guy l'll call "Dutch" who I met in San Pedro and with whom I lived for about two years. He was a seaman on steam schooners on the west coast. I stayed involved with Dutch for so long - this is a dreadful confession - because I felt it was my Party duty to do it. We needed to have a seaman stay on the beach. And he was lonely and he was one of our best members and if that's what he wanted, and it's what he did want, then it was my Party duty to give him what he wanted. 102

Years later, Healey described this as her "Salvation Army' approach to love and marriage. You're bestowing yourself because that's what somebody else wants and what do you care?"103 Sharing a bed with the sailor, not because of mutual physical attraction but from a sense of "Party duty," had become political as well as sexual labour.

The sexual practices of the Left, however, cannot be characterized as simply utilitarian. ${ }^{104}$ At times radical activists were drawn together sexually, precisely because of their shared politics and shared participation in cultural activities. Frequently, friendship and fictive kin networks provided both a place for radicals to come together and a jumping off point for the dissolution of sexual unions. 
Moreover, those on the Left did not share a single common ideology about sex, gender relations, or the appropriateness of marriage and monogamy. Left activists, like those of any political persuasion, were not uniform nor consistent in their theory and practice of sexuality. Tangled in the mix of sex and politics were heated private debates and personal struggles over the meaning of sexuality and the content of women's equality. In this context, opposition to private property was one thing; but sexual and emotional possessiveness were far more common than anyone would like to admit. ${ }^{105}$ Even those who chose nonmonogamy found themselves confronted with personal feelings of envy and jealousy. Conflict over sexual orientation and the meaning of new sexual identities and practices surfaced.

Sexual bonds among those on the left were often forged in the homes of friends. In the 1920s, communist writer Genevieve Taggard's Greenwich Village flat served as a place where Josephine Herbst (among others) stayed while acclimating to New York. Gatherings there reflected the emotional tenor and sexual excitement of Left politics. According to Herbst's biographer, "Every day after work the apartment was open for flirtation and conversation and between the politics, the poetry, and the overwhelming awareness of sexual possibility, the mood was always intense." There, Helen Black, Jessica Smith, Mike Gold, Max Eastman, Joseph Freeman, and Floyd Dell gathered and talked of "loveand-revolution." 106 Against this backdrop, Herbst began an affair with the married playwright Maxwell Anderson. Whether in such heady intellectual settings or in more homey settings such as the living room of Junius and Sylvia Scales in Chapel Hill, "the conversation was often political but by no means exclusively so ... and the discussions were often very lively." Such evenings helped to bring Party activists, sympathizers and supporters together both personally and politically. ${ }^{107}$ Similarly, Mark Litchman retained into the mid1920 s his practice of Saturday evening gatherings for Seattle area radicals of all shades; there, many new sexual unions were known to form. ${ }^{108}$

More formal party functions also brought people together. Peggy Dennis recalled that she first met Eugene Dennis in 1928 at the Pacific Coast Marxist Summer School, where they spent long hours together. "Sometimes gently, sometimes provocatively, sometimes harshly, sometimes humorously, we probed and challenged each other as man and woman, as revolutionaries, as human beings." She was brought up short when at the end of the school, Gene asked her what she was going to do about her husband Bill. In her autobiography, she recalled that she had known Bill for years: "We had been active together in our radical movement in Los Angeles, and we had gotten married." Their relationship was that of "comrades among other comrades, involved in movement activity together, but not deeply, irrevocably involved with each other." 109 She decided to divorce Bill and follow her "love."

Differences within the Communist Party and the Left as a whole existed over what theories of sexuality and marriage would guide proletarian and 
revolutionary sexual behavior. Dorothy Healey recalled that in the $\mathrm{CP}$ in theory there "was no such thing as a division between your personal and your political life. You were supposed to be totally selfless and dedicated to the revolution."Yet men and women of the Left argued about what was appropriate sexual morality. Healey recalled a fight she once had with Archie Brown, future ILWU leader and then "a rough, tough YCL newsboy":

I had just read Krupskaya's Memories of Lenin, and the thing that impressed me was on the question of sex, how Lenin had decried promiscuity, using the example of the glass of water - that just as you wouldn't want your lips to be on a glass that was muddied by other people's lips, the same was true in a sexual relationship. Archie was having a lot of interesting sexual relationships at the time, and I told him this story very self-righteously. After all Lenin had said it, and anything Lenin said was supposed to be the final word on any question you wanted answered. I was absolutely appalled when Archie turned to me and said, "Look, I will follow anything that Lenin says on politics, but I understand that in Lenin's apartment there were two very narrow beds at opposite ends of the bedroom, one for Krupskaya and one for Lenin, and they didn't even sleep together. That guy knew nuttin' about sex! That's for sure! And I'm not taking my leadership from him!" I was very shocked at this. ${ }^{110}$

Archie and Dorothy recapitulated Lenin's arguments with Alexandra Kollontai over her advocacy of "comrade love" as a sexual ideal. Kollontai believed that sexual freedom was a necessary condition for revolution, because individual possessiveness, even in intimate relationships, undermined collective solidarity. As she wrote, "Solidarity is not only an awareness of common interests; it depends also on the intellectual and emotional ties linking the members of the collective." When love-solidarity replaced the possessiveness of bourgeois love, Kollontai argued, "The blind, all-embracing, demanding passions will weaken; the sense of property, the egotistical desire to bind the partner to one 'forever,' the complacency of the man and the self-renunciation of the woman will disappear." 111 While Archie may have had in mind something less collective in his sex life, he disdained Lenin's prudery in favor of his own sexual practice.

Brookwood Labor College graduate and radical black activist Thyra Edwards maintained a theory and practice of sexuality which did not fit into the theoretical restrictions of the Communist Party in the 1930s. While she wrote no autobiography, some of her ideas surfaced in her correspondence with friends. Touring workers' educational facilities in Europe in 1934, Edwards wrote to her married lover and promised him that she wouldn't "extend any more invitations to paternity," as it disturbed him. ${ }^{112}$ Writing to a friend about an afternoon she spent with a young male Swedish philosopher, she explained that the two:

sat down to talk, of men and wome[n], of sex, of children, of marriage, of the philosophy of Bertrand and Dora Russell and of those who preach sexual liberty but carefully adhere to orthodoxy. We were agreed that one must have a 


\section{Left History 7.1}

super sense of physical security and sureness in his partner to condone outside relations. But then we agreed that with so strong and vital a union between two persons there would be little occasion for outside affairs. And so, dialectically, we disposed of sexual freedom as distinguished from tolerance or from free love.

Far from seeing sexuality as separate from politics or life, Edwards commented that it was a "relief to really talk to another" as "most people haven't the courage to face themselves, much less others and speak of the things that occupy much of all our thinking." 113 While working with Spanish refugees in Mexico, she wrote to another friend that she was feeling better either from rest or from a "transient," "very satisfactory," and "comforting" love affair. In this letter, Edwards explained that she "never wanted to be married in the routine way most of [her] friends are."114 Like anarchist Emma Goldman, Edwards viewed sexuality and relationships as central to politics and community.

Giving sexuality a central place in political life, Edwards' perspective contrasted with the prudery, silence, and sexual reticence of some more rigid Leftists. Charles Shipman was never comfortable with the pre-World War I Left's linkage of sexual and radical politics. Recalling his days at Columbia in the mid-1910s as a young journalist student and member of the Intercollegiate Socialist Society, Shipman expressed his opposition to mixing class struggle with "frivolous" things like sexuality, "psychoanalysis" and birth-control. They were "out of place" in revolutionary politics. ${ }^{115}$ According to his own account, Shipman did not understand "the woman question" in the interwar years, nor did he apply the communist standard of equality to his sexual practice. While in the Soviet Union for the Second Congress in 1920, he began an affair with Natalie Mikhailova, his eighteen-year old translator, whom he described as a "surprisingly ignorant" "thing of beauty." Despite the fact that he was not legally divorced, Shipman joined Natalie in what he described as "a marriage of convenience." For his trouble, he got "a satisfactory bedfellow," who "relied on" him, "asked little for herself," "kept confidences, and was fiercely loyal."116 In his autobiography, he explained both the role Natalie played for him and the end of the marriage:

Natalie had adjusted her life to mine as best she could, running a Communistoriented household on little or nothing, with serenity and discretion, whatever the hours and whoever might drop in unexpectedly. She went with me to Communist-run picnics, festivities at comrades' homes, and so on, but never to political meetings, public or private ... Midway through 1926 we broke up. It should have happened sooner. In the final months - and years - I treated her abominably, hurting her with derogatory remarks on her Hollywood tastes, her idle daydreaming, and her intellectual vacuity. My behavior was destructive and cruel. I was ashamed of myself afterward. 117

What he had wanted was a bedmate, cook, and helper who did not compete with him politically, economically, or socially. Only in retrospect did Shipman 
understand the implications of his choice.

The literary Left could and did express in practice a similar disdain for ideas or practices of sexual equality. In a 1931 letter to her friend Katherine Anne Porter, writer Josephine Herbst wrote of being excluded from discussions of the Scottsboro case and revolutionary politics by her husband, John Herrmann, and his friends communist Mike Gold and fellow travellers Edmund Wilson and Malcolm Cowley. Rather than seeing her as a fellow comrade, Herbst was reduced to "that very caricature she had sworn all her life to avoid: 'John's wife." 18 She reported on the "masculine importance" John exhibited at being included in the beer-lubricated discussions and the "stay-in-your-place" attitude which he used to decline her company. Herbst recounted that she "told Mister Herrmann that as long as the gents had bourgeois reactions to women they would probably never rise very high in their revolutionary conversations." As she herself claimed, she "never wanted to be a lady." What she wanted instead was "to be a woman and a Mensch in Rosa Luxemburg's terms." 119

The private and public sexism of Left men exacerbated tensions arising from unequal relationships, neglect, and infidelity. At times, the breaking of personal bonds could and did result in increased emotional conflict among individuals on the left, internal divisions within political organizations, and factionalism. Having fled with his wife, Eleanor, to Mexico, Charles Shipman continued his extensive involvement with radical politics to the exclusion of Eleanor. While they worked together in the English language branch of a Mexico City paper during the day, at night Charles went to union and radical meetings, leaving Eleanor to fend for herself. She proceeded to explore the art and radical community in Mexico with a co-worker, Glint. According to Shipman, Eleanor and Glint "were going to bed together." Charles experienced both rage and jealousy: "Theoretically libertarian in such matters," he explained, "I was supposed not to care. But I did. Fiercely. When I insisted it had to be him or me, she went to live with Glint." The breakup resulted not just in great distress for Shipman, but also in serious problems in regard to the paper: "as if nothing had happened, I had to face Eleanor and Glint everyday at the office. The only alternative would be to fire them, which was unthinkable. They stayed with the English Section to the end. My only relief was work. I have never worked more obsessively - all day at the office, then half the night in labour halls and committee rooms." 120

Similarly, Joe Pass, a close associate of Puget Sound activist Kate Sadler, recalled that when Kate's husband, Sam, had an affair, Kate fell apart, as did her political organizing:

The beautiful constructive flame in [Kate] wheeled into a destructive direction. (Sam acted like a damn fool.) This mature \& practical woman lost her balance, derailed into a lifeless valley where rage against fate was her only outlet. Her love, her dream, her humour turned to ashes. The only element of life sustaining her during that period was her political 


\section{Left History 7.1}

convictions. But the flame was extinguished. The soapbox collapsed under her. And our wonderful, practical Kate lacked the strength to be of any assistance to us during a time when we needed her most. ${ }^{121}$

The New York Theater Union also suffered when its financial problems were exacerbated by shifting sexual alliances. According to Shipman, "When Margaret Larkin switched from Liston Oak to Albert Maltz, it poisoned relations between Liston and Albert."122

Sexuality could prove divisive on the Left for several reasons. Perhaps none was more charged than the issue of homosexuality. Men on the Left could and did become offended when they were on the receiving end of male sexual advances; lesbian relationships could present a threat or represent a quaint deviation. Liberator" 123 contributor Adolf Dehn explained that he was "startled and disturbed to realize" that Liberator editor Claude McKay was "indubitably making homosexual overtures to" Dehn. His response was to cut off all contact with McKay. ${ }^{124}$ Radical men wrote almost ritually in their autobiographies of the homosexual advances made to them in their youth. ${ }^{125}$ These recollections are less evidence of profound sexual difference on the Left than of the changing sexual climate of the twentieth century. Just as left marriages increasingly were subject to the social pressures and psychological expectations that led apolitical couples to divorce more readily in the twentieth century, so too did men and women on the Left encounter new sexual identities and behaviors. As George Chauncey and Carroll Smith-Rosenberg have argued, the roles of "homosexual" and "lesbian" were emerging from 19th century sexual practices and beliefs. By 1920, the new sexology labelled same-sex relationships "deviant."126

The American Left had its own encounter with the brave new world of sexology that Edward Carpenter and Havelock Ellis inhabited. It was a world that many leftists viewed with skepticism, homophobia, and disdain. John Collier's "enlightened" views on non-monogamous relationships did not keep him from characterizing young radicals in Boston as "semi- or pseudo-per(or in-)verted." As he wrote to his former wife, Miriam deFord, one of them, Otto Larson, "a high-rolling young brute from Norway, running around with Reds," tried to "devour" Collier's lover Phyllis with "lustful eyes." Larson's "Oscar Wilde affectedness" and "uncouth advances" repulsed Collier, even as he was theoretically committed to Phyllis's own sexual self-discovery. The effeminate nature of the young men, along with what Collier characterized as "unresisting and undiscriminating sexual adventure and promiscuity," were, from his perspective, "per/in/verted." (Interestingly, Collier also thought monogamy perversion.) $)^{127}$

After their mutual friend composer George Edwards committed suicide, Armistead wrote Miriam, "I was very fond of Geo. Edwards - in spite of our pronounced differences - and respected him for his manly attitude and defense of his unpopular tendencies and principles. I thought that, like Edward Carpenter, he believed in the righteousness of his sexual variations. And I 
thought the girl who had been so long in love with him married him with understanding and acceptance of his congential ways of sex expression." His "unpopular tendencies" aside, Collier wanted to know why Edwards had killed himself. Miriam responded by discussing the increasingly difficult life Edwards led: "I think myself it was just everything together sweeping over him that was too much for him - the danger and lack of understanding he met because of his homosexuality, the wreck of his only normal love affair, the loss of his child, his having accomplished so little." Edward's decision to be psychoanalyzed and thus "cured" of his homosexuality played a role, not simply in the personal crisis that led to suicide, but in the analysis of both Collier and deFord. While they accepted Edward's "congenital ways of sex expression," remained "fond of him," and felt his suicide "bitterly," deFord and Collier accepted as well that his lifestyle was deviant. ${ }^{128}$ In their attitudes, Collier and deFord reflected only a slightly more enlightened view of homosexuality than was normally held on the twentieth century Left. Like Emma Goldman, they embraced the new sexual science, tolerated and even defended homosexuality publicly, and created close friendships with gay men and lesbians. But as with the question of women's sexual emancipation, these Leftists also embraced double standards and denials when it came to same-sex bonds. They could not perceive that such relationships would provide the same kind of support for left activism as did their own networks of lovers and friends. ${ }^{129}$

Despite the official Communist Party stand on homosexuality, which following Stalinist policy, considered homosexual practice incompatible with revolutionary activity and working-class consciousness, there were a large number of gays and lesbians active in the Party as elsewhere on the Left. When local leader Junius Scales was asked to help reduce the Party to "its hard core of trusted and tested members," he was ordered to inquire into each member's sex life. Scales was startled to find a number of positive responseb to the question, "Are you either homosexual or bisexual?" "Affirmative replies," Scales wrote, "came from old and young, men and women, Negro and white, married and single, workers and students. Two prominent Negro unionists, two outstanding student leaders, and others exceptional in their ability and activity included themselves among the homosexuals." After consulting with another local Party leader and talking with "a number of homosexual comrades," Scales "concluded that the Party's position was wrong and superficial." He recalled being impressed with "the homosexuals' willingness to reveal to the Party something so deeply hidden away. Such courage and such trust in the Party scarcely supported the theory of their vulnerability to blackmail." Scales simply declined to enforce the directive to remove gays and lesbians from the Party. ${ }^{130} \mathrm{He}$ was not alone in his willingness to work alongside gay and lesbian comrades. ${ }^{131}$

CONCLUSION

This essay may well be an exercise in re-discovering the known world. The 
dependence of political movements on family and friendship networks, sexual unions, and cultural activities is not a new revelation, though - from the usually grim portrait of the American Left - one could assume no radical cracked a smile from 1919 to the present day. The remarkable, prolific, and intense personal correspondence that allows us to see social networks in action has been almost unnoted by historians of radicalism and labour movements, who use primarily newspapers and polemics and occasionally oral histories, memoirs, novels, and the dryest political excerpts from otherwise lively letters. The interwar Left in particular has suffered from an overly serious and rather ideological perspective. No one knows what to make of the sexual scandals and wacky partnerships that made the Leftist letter writers, memorists, and organizers a vibrant force in their own time, if not in our understanding of their history.

The question is then why the Left's personal lives and loves have been resigned to the dustbin of history. Reasons vary from the traditional methodology and focus of studies of the Left (with a longer adherence to the history of cadres, parties, and literature than that of labour history) to the presumed lack of appropriate sources. Some of this sexual reticence falls to the self-image of invulnerability and respectability held by the Left. In William $Z$. Foster's autobiographical writings, as both Edward Johanningsmaier and James Barrett have told us, there are few references to either his family of origin or to his long-term marriage with sexual varietist and anarchist Esther Abramowitz. Ella Reeve Bloor's own sexual history was hidden behind the mask of her public persona as "Mother Bloor."132 Sexuality, and advocacy of free love in particular, cast the Left as a disreputable, immoral, and corrupting force in society. Accusing the Left of sexual impropriety has been one of the surest ways to silence dissenting voices.

As Emma Goldman found out when her autobiography, Living My Life, was published, the strange sexual reticence of the Left prohibited its adherents from seeing personal life as important for a life of struggle. And yet there were and are those who see the connections between political activism and personal life cannot be wholly denied. Respect for the right of privacy, oddly protected in a political movement built on opposition to private property, helped to reinforce silence, as did the wave of anti-communism in the 1950s and sexism and homophobia throughout the twentieth century. So, too, did the distrust of egotism, especially in women. Finally, left criticism of revelations of personal life grew out of the belief that autobiographical and political writings were designed to be educational for the young and to uphold Left lives as exemplars of a future society. ${ }^{133}$ As Lucy Parsons wrote of Goldman's book, Goldman had set "herself down a fool." Goldman's accounts of herself and her lover Ben Reitman were "simpley [sic] disgusting! to anyone who have [sic] anything but a debased depraved mind." If Goldman "had left out the sex stuff," Parsons believed, "the book would have appealed to a more thoughtful element." 134 
Separating out sexuality and personal life from the life of politics was - in the minds of anarchists, socialists, communists and other interwar radicals - a sensible and rational thing to do in theory. But if the lives and letters of the Left are any evidence, it was something they rarely found possible or advisable to do in practice.

'We want to thank Steve Meyer, Kathleen Kennedy, Jeet Heer, Patrick Connor, Beth Bates, and the anonymous reviewers of Left History for their insights and suggestions. ${ }^{2}$ William Armistead Nelson (John) Collier has no biographer. His voluminous papers, which capture his wide-ranging and sometimes tortured struggle with radical and spiritualist ideas, are housed at the Archives of Labor and Urban Affairs, Walter P. Reuther Library, Wayne State University (hereafter ALUA). In his lifetime, Collier published a number of short essays; and a volume of his poetry, complete with excerpts from private correspondence, was published as John Armistead Collier, In the Wilderness: Poems of Pessimism from the Journal of a Rebel and Mystic (Los Angeles 1948).

${ }^{3}$ Francoise Delisle, Francoise: In Love with Love, (proof copy), of a reprinted book, (London 1964), originally published as Friendship's Odyssey (1946). John and Phyllis Collier Papers, Box 25, file 17. In the original version, the names were changed.

${ }^{4}$ H.M. Wicks, 'Apology for Sex Anarchism Disguised as Marxism,' Daily Worker 19 June 1927. This is in response to John Darmstadt [pseud.], 'The Sexual Revolution,' Modern Quarterly IV:2 (1927), reprint in John and Phyllis Collier Papers, Box 2, Folder 'The Sexual Revolution, 1927.' See also correspondence with Floyd Dell and V.F. Calverton in box 2; Charles W. Wood, 'Don't Fight with Sex: Scientific Attitude for Proletarian Revolutionists,' New Masses (February 1927), 7-9,31ff; Leonard Wilcox, V.F. Calverton: Radical in the American Grain (Philadelphia 1992), 69-97, where Collier is identified as John Darmstadt.

${ }^{5}$ Theodore Draper's The Roots of American Communism (New York 1957) and American Communism and Soviet Russia: The Formative Period, reprint edition, with a new Introduction and Afterword, (New York 1986, c.1960), both focus on ideology almost exclusively. Harvey Klehr, The Heyday of American Communism: The Depression Decade (New York 1984) similarly ignores the cultural and personal politics of the Party to focus on ideology and theory, as does Fraser M. Ottanelli, The Communist Party of the United States: From the Depression to World War II (New Brunswick, NJ 1991). A more recent study, Edward P. Johanningsmeier, Forging American Communism: The Life of William Z. Foster (Princeton 1994), does little with Foster's personal life and even less with his network of friends.

${ }^{6}$ Vivian Gornick's The Romance of American Communism (New York 1977); Judy Kaplan and Linn Shapiro (eds), Red Diapers: Growing Up on the Communist Left (Urbana and Chicago 1998). Two recent works that begin to address connections in the interwar Left between the cultural and the political are Robbie Lieberman, 'My Song is My Weapon': People's Songs, American Communism, and the Politics of Culture, 1930 1950 (Urbana 1995) and Paul C. Mishler, Raising Reds: The Young Pioneers, Radical Summer Camps, and Communist Political Culture in the United States (New York 1999). For a recent synthesis of material on proletarian and Popular Front culture, see Michael 


\section{Left History 7.1}

Denning, The Cultural Front: The Laboring of American Culture (London \& New York 1997). We owe a debt to Sara Evans, Personal Politics: The Origins of Women's Liberation in the Civil Rights Movement and the New Left (New York 1978), and Shirley J. Yee, Black Women Abolitionists: A Study in Activism, 1828-1860 (Knoxville 1992), among others who have explored the connections between personal and political activism.

${ }^{7}$ Elinor Langer, Josephine Herbst (Boston 1984), 213.

${ }^{8}$ Dorothy Healey and Maurice Isserman, Dorothy Healey Remembers: $A$ Life in the American Communist Party (New York 1990), 22.

${ }^{9}$ Ibid., 25-26, 35.

${ }^{10} \mathrm{Al}$ Richmond, A Long View from the Left: Memoirs of an American Revolutionary, (Boston 1973), 70. For LeSueur, see Crusaders (New York 1955), her biography of her mother, Marian LeSueur, and her stepfather, Arthur LeSueur. On Broms, see his papers in the Minnesota Historical Society [hereafter MHS].

${ }^{11}$ Paul Siegel, "Tribute to George Breitman" in Naomi Allen and Sarah Lovell (eds.), A Tribute to George Breitman: Writer, Organizer, Revolutionary (New York 1987), 39; and Editorial Board of Bulletin in Defense of Marxism, "George Breitman (1916- 1986): More than Half a Century of Revolutionary Dedication," in ibid., 157.

${ }^{12}$ Sherman Labovitz, Being Red in Philadelphia: A Memoir of the McCarthy Era (Philadelphia 1998), 42-43.

${ }^{13}$ Albert Vetere Lannon, Second String Red: The Life of Al Lannon, American Communist (Lanham, MD 1999), 55-56.

${ }^{14}$ Robert Schrank, Wasn't That a Time? Growing up Radical and Red in America (Cambridge 1998), 7, xi, 49. Ironically, when Schrank joined the Young Communist League, spoke out against a friend of his father's, and rejected the "German authoritarian" streak, his father accused him of being a Stalinist and kicked him out of the house. Schrank's reply to his father was "I can't understand why I'm being punished for doing what you taught me" (115).

${ }^{15}$ Eugene V. Dennett, Agitprop: The Life of an American Working-Class Radical (Albany $1990), 1,4,8,12-14$. Leftist poet James Rorty's political radicalization began in his father's Irish nationalist household in upstate New York. See Alan Wald, The New York Intellectuals: The Rise and Decline of the Anti-Stalinist Left from the 1930s to the 1980s (Chapel Hill 1987), 54. Another famous case is Elizabeth Gurley Flynn's family connection between Irish nationalism and socialism, relayed in her autobiography, The Rebel Girl: An Autobiography, My First Life (1906-1926), new edition, (New York 1973, c. 1955), chapter 1.

${ }^{16}$ Interviews with Marvel Cooke, recorded by Kathleen Currie for the Washington Press Club Foundation as part of its oral history project, Women in Journalism (Washington, DC 1990), 6, 26, 74. On Hilbert, see Hilbert family correspondence with Ella Reeve Bloor, Ella Reeve Bloor papers, Sophia Smith Collection, Smith College (hereafter Bloor papers).

${ }^{17}$ Vivian Gornick writes of her own childhood, "Before I knew that I was Jewish or a girl I knew that I was a member of the working class." Romance of American Communism, 3. On others, like Gornick, of a later Red Diaper generation, see also Kaplan and Shapiro (eds), Red Diapers; Griffin Fariello, Red Scare: Memories of the American Inquisition; An Oral History (New York 1995), 47-69.

${ }^{18}$ Peggy Dennis, The Autobiography of an American Communist: A Personal View of a 
Political Life, 1925-1975 (Westport, CT 1977), 20-23, 26. Born Regina Karasick, she took the Party name Reggie Carson and in 1935 adopted the name Peggy Dennis.

${ }^{19}$ Vivian McGuckin Raineri, The Red Angel: The Life and Times of Elaine Black Yoneda (New York 1991), 7, 9.

${ }^{20}$ Ibid., 13, 23-25, 40, 47.

${ }^{21}$ Dennis, Autobiography, 20.

${ }^{22}$ Gornick, Romance of American Communism, 51 .

${ }^{23}$ Healey and Isserman, Dorothy Healey Remembers, 62.

${ }^{24}$ Lannon, Second String Red, 56, 94.

${ }^{25}$ Ann Kimmage, An Un-American Childhood (Athens 1987), 29.

${ }^{26} \mathrm{Ibid} ., 30$.

${ }^{27}$ Ibid., 33. Peggy Dennis tells a similar story in her autobiography to demonstrate the centrality of the left's "counter-community" and expose the importance of spouses for the left. While Belle at times saved Abe's political career, Peggy Dennis' mother saved her husband's life. When their home was stormed by an "angry lynch mob" made up of "white, Gentile neighbors" angry that they had sold their cottage to a Japanese family, "Mama locked Papa in the bathroom, over his angry protests. He wanted to lecture the mob about the equality of all races .... But Mama's tactics were more pragmatic and survival-oriented." Mama stalled the mob while Peggy ran to "phone the uncles for help." Dennis, Autobiography, 22.

${ }^{28}$ See Constance Coiner, Better Red: The Writing and Resistance of Tillie Olsen and Meridel LeSueur (Urbana 1995).

${ }^{29}$ Basha [de Ward] to Harvey O'Connor, 8 December 1932, 9:9, Harvey O'Connor Papers, part 2, ALUA.

${ }^{30}$ On Pesotta and Hapgood, see Rose Pesotta, Bread Upon the Waters, (ed.) John Nicholas Beffel, with a new introduction by Ann Schofield, (Ithaca 1987), vi, 198ff; Elaine Leeder, The Gentle General: Rose Pesotta, Anarchist and Labor Organizer (Albany 1993), 128-136. For Goldman and Berkman, see Candace Falk, Love, Anarchy and Emma Goldman (New York 1984); Richard and Anna Marie Drinnon, eds, Nowhere at Home: Letters from Exile of Emma Goldman and Alexander Berkman (New York 1975); Margaret Collingwood Nowak, Two Who Were There: A Biography of Stanley Nowak (Detroit 1989). Farrell Dobbs, Teamster Rebellion (New York 1972), introduces the volume by thanking Marvel Scholl, his wife, for the use of her diary from the 1934 strikes in his account. In subsequent volumes, he uses long passages from her diary. See also Marjorie Penn Lasky, "'Where I Was a Person': The Ladies' Auxiliary in the 1934 Minneapolis Truckers' Strike," in Ruth Milkman (ed), Women, Work and Protest (Boston 1984), 181-205.

${ }^{31}$ On Hutchins and Rochester, see Janet Lee, "Grace Hutchins," Encyclopedia of the American Left, eds. Mari Jo Buhle, Paul Buhle, and Dan Georgakas, second edition, (New York; Oxford 1998), 343-345; Lee, “Anna Rochester," ibid, 701-703, and idem, Comrades and Partners: The Shared Lives of Grace Hutchins and Anna Rochester (Lanham, MD 2000); see also their papers in the Knight Library Special Collections, University of Oregon, and correspondence with Harvey O'Connor in the O'Connor Papers. On Mason and Foster's relationship see John A. Salmond, Miss Lucy of the CIO: The Life and Times of Lucy Randolph Mason, 1882-1959 (Athens 1988), 119-123. On Grace Carlson and Vincent Dunne, see the Grace Carlson papers, MHS; on the Stockwells, see Dorothy Walton Binder, "The Stockwells of Minnesota," New Republic 
93 (22 December 1937), 194.

${ }^{32}$ Hannah to Jacob, 25 November 1921; Hannah to JBS Hartman, 30 November 1921; Hannah to JBS Hartman, 29 December 1921; and JBS Hartman to Hannah 21 December 1921 , 3:15, JBS Hartman Papers, Tamiment Library, New York University. On Herbst and the O'Connors, see Langer, Josephine Herbst, 149-151; Jessie Lloyd O'Connor, Harvey O'Connor, and Susan M. Bowler, Harvey and Jessie: A Couple of Radicals (Philadelphia 1988).

${ }^{33}$ Junius Irving Scales and Richard Nickson, Cause at Heart: A Former Communist Remembers (Athens 1987), xxxii. The introduction quotes Murray Kempton that Woody Guthrie argued "the Communist Party represented socialism of the hearth," xxxiii.

${ }^{34}$ Ibid., 69, 71, 75.

${ }^{35}$ Healey and Isserman, Dorothy Healey Remembers, 28, 37, 38.

${ }^{36}$ Kimmage, An Un-American Childhood, 6.

${ }^{37}$ Ibid., 118.

${ }^{38} \mathrm{Federal}$ Bureau of Investigation report, 'Mrs. Ella Reeves Bloor, Alleged Communist Activities,' 3 January 1922, 61-155-[?], Ella Reeve Bloor FBI file, obtained through Freedom of Information Act request.

${ }^{39}$ Ella Reeve Bloor [hereafter ERB] to Richard (Dick) Reeve, Monday, n.d. [1928], (un30-16), Ella Reeve Bloor Papers [microfilm edition], Sophia Smith Collection, Smith College, (hereafter ERBP film).

${ }^{40}$ See for instance, ERB to Helen Ware Chappell, 22 May, (un-20-11); ERB to Richard (Dick) Reeve[?], [July 1924], fragment, (24-2); ERB to Dick, 24 August, (26-11); ERB to Dick, 22 April, (26-2); ERB to Dick, 15 June [1926], (26-9); ERB to Dick, 24 August, (26-11); ERB to Dick, 21 July, (33-23); ERB to Hamilton (Buzz) Ware, 3 December, [1928], (un-20-36); ERB to Dick, Celia, and Dorothy Hilbert, 24 August, (28-13), ERBP Film.

${ }^{41}$ ERB to Hamilton (Buzz) Ware, 9 October 1928, (28-15), ERBP Film.

${ }^{42}$ ERB to Richard (Dick) Reeve, 19 January, (26-1), ERBP Film.

${ }^{43}$ See Mark Litchman correspondence with Emanuel Slater,1:30-35, Mark Litchman Papers, Manuscript and University Archives, University of Washington Libraries, Seattle. See also Litchman's correspondence with Len De Caux.

${ }^{44}$ Mark Litchman to Eugene Belmont, 2 September 1920, 1:29, Litchman Papers.

${ }^{45}$ Harvey O'Connor to Barbara, 25 October 1931, 9:7, O'Connor Papers, part 2.

${ }^{46} \mathrm{Henry}$ Bengston, On the Left in America: Memoirs of the Scandinavian-American Labor Movement, translated by Kermit B. Westerberg, edited and with an introduction by Michael Brook (Carbondale and Edwardsville, IL 1999), 137, 123, xiii, xiv.

${ }^{47}$ Autobiography of Barney Mayes, manuscript (photocopy), untitled, n.d., 342, 413-414, Labor Archives and Research Center, San Francisco State University.

${ }^{48}$ Christopher Phelps, Young Sidney Hook: Marxist and Pragmatist (Ithaca 1977), 34.

${ }^{49}$ Sam Darcy to Leo and Hannah Gallagher, 18 February 1962, Box 1, ff 24, Sam Darcy Papers, Tamiment Library.

${ }^{50}$ Charles Shipman, It Had to Be Revolution: Memoirs of an American Radical (Ithaca 1993), xx.

${ }^{51}$ Ibid., 148, 147, 204, 209-210, 229.

52 For the correspondence, see the John and Phyllis Collier Papers; Miriam deFord Papers, California Historical Society, San Francisco; Maynard Shipley Papers, Bancroft Library, University of California, Berkeley. See also Miriam Allen deFord, "On the 
Soapbox," in Sherna Gluck, ed., From Parlor to Prison: Five American Suffragists Talk about Their Lives, (New York 1976), 124-79; Miriam Allen deFord, Uphill All The Way: The Life of Maynard Shipley (Yellow Springs, $\mathrm{OH}$ 1956). For sample letters, see Maynard Shipley to Armistead, 14 December 1918, Box 24, and Miriam to Armistead, 15 October 1926, Box 25, Collier Papers.

${ }^{53} \mathrm{John}$ Abt, Advocate and Activist: Memoirs of an American Communist Lawyer (Urbana 1993), 21-22.

${ }^{54}$ Ibid., 21, 41 .

${ }^{55}$ Kate Sadler Greenhalgh to Jessie and Harvey O'Connor, January 1937, 17:97, O'Connor Papers, part 2.

${ }^{56}$ Art Shields to Harvey O'Connor, 11 March 1929, 18:10, O'Connor Papers, part 2. See file 18:10 for more correspondence.

${ }^{57}$ Raineri, Red Angel, 214.

${ }^{58}$ Ibid., 219. The importance of such visits was underlined during the Smith Act trials of the $40 \mathrm{~s}$ and $50 \mathrm{~s}$. While some jailed communists spoke of mail from their comrades as the center of their resistance to the emotional turmoil of incarceration, Al Richmond recalled the joy of hearing about 500 pickets marching and singing ('Solidarity Forever') to demand bail in front of the LA jail. Richmond, A Long View from the Left, 320-21. "Those people on the streets, bless them. Jail, Judge Mathes, the jangling pressures of political crosscurrents, the bad dream that is a long political trial - through all this and against all this was the vibrant solidarity of those people; comradeship, devotion, generosity, affection. This was one human element of the Communist movement at its finest." Effectively denied bail, the California Smith Act defendants were allowed to meet with witnesses and attorneys in a facility outside of their individual jail cells and to arrange for food to be served during those meetings. According to Richmond, the "political catering service drew on the culinary resources of the Left community in Los Angeles; each meal was a voluntary labor of love and political conviction." For Richmond, it was the physical support, not the letters which sustained him: "I cherish the cooks and the typists, their constancy and care, with a particular warmth, but there were other manifestations of bracing support: bodies and souls on picket lines, at the several mass rallies, and in the courtroom, where the benches were filled with our silent witnesses." Ibid., 321-22; see also Healey and Isserman, Dorothy Healey Remembers, 137.

${ }^{59}$ See, for instance, Fred Fine to Doris Fine, 11 January 1942, 2:[3] '1942 (Jan-Feb),' Fred Fine Papers, Chicago Historical Society [CHS], (hereafter Fine Papers).

${ }^{60}$ J.P. Cannon to Grace Carlson, 22 February 1940, 'SWP Correspondence file 1, 1939 1942,' Box 1, Carlson Papers, MHS.

${ }^{61}$ There are several folders of letters in the Carlson papers from Carlson's prison term, including a folder of children's letters and drawings and Carlson's prison notebooks. For her homecoming, see Dorothy to Grace, [January 1945], dated Thursday, which documents the search for an appropriate homecoming girdle; Dorothy to Grace, 3 January 1945, about her clothing; and Ben to Grace, 3 January 1945, on the "Rose." All in 'SWP Correspondence, January-June 1945' folder, Box 1, Carlson Papers.

${ }^{62}$ Healey and Isserman, Dorothy Healey Remembers, 39.

${ }^{63}$ Scales and Nickson, Cause at Heart, 64.

${ }^{64}$ Labovitz, Being Red in Philadelphia, 15.

${ }^{65}$ Kimmage, An Un-American Childhood, 30.

${ }^{66}$ Shipman, It Had to Be Revolution, 167, 178. 


\section{Left History 7.1}

${ }^{67}$ Jessie to Harvey, "Friday 314", d.d. [c. 1937], 14:5, O'Connor Papers, part 2.

${ }^{68}$ Esther Lowell to Harvey and Blanche O'Connor, 3 May, 18:11, O'Connor Papers, part 2.

${ }^{69} \mathrm{Abt}$, Advocate and Activist, 76, 95.

${ }^{70} \mathrm{c} 96-97$.

${ }^{71}$ Ibid., 176.

${ }^{72}$ Ibid., 181-82.

${ }^{73}$ Anne Branden, typed manuscript review, 'Harvey and Jessie: A Couple of Radicals,' box 8 , ff 22, O'Connor Papers, part 2.

${ }^{74}$ Horace B. Davis to Harvey, 2 July [1952], 13:4, O'Connor Papers, part 2.

${ }^{75}$ Tom O'Connor to Harvey, 1 October [1928], 17:14, O'Connor Papers, part 2.

${ }^{76}$ Labovitz, Being Red in Philadelphia, 12, 9.

${ }^{77}$ Nowak, Two Who Were There, 74, $131 \mathrm{ff}$.

${ }^{78}$ Hays [Jaze] Jones to Harvey O'Connor, 22 August 1921, 14:47, O'Connor Papers, part 2.

${ }^{79}$ Hays [Jaze] Jones to Harvey O'Connor, 6 September 1921, 14:47, O'Connor Papers, part 2.

${ }^{80}$ Hays [Jaze] Jones to Harvey O'Connor, [22 December 1921], 14:47, O'Connor Papers. part 2.

${ }^{81}$ Hays [Jaze] Jones to Harvey O'Connor, 2 April 1922, 14:47, O'Connor Papers, part 2. ${ }^{82}$ ERB to Helen Ware Chappell, 10 November, (25-10); ERB to Richard (Dick) Ware, 14 November, (25-11), both in ERBP Film.

${ }^{83}$ For detailed analysis of Bloor's friendship networks, see Kathleen A. Brown, 'Ella Reeve Bloor: The Politics of the Personal in the American Communist Party,' Ph.D. thesis, University of Washington, 1996, chapter 3.

${ }^{84}$ Hope Hale Davis, Great Day Coming: A Memoir of the 1930s (South Royalton, VT 1994), 326.

${ }^{85}$ Wayne Cooper, Claude McKay, Rebel Sojourner in the Harlem Renaissance: A Biography, reprint, (New York 1990, c.1987), 168-69, 199-200, 209-10.

${ }^{86}$ Max Bedacht, 'On the Path of My Life,' unpublished memoir, 242, 244-45, Coll \# 72, box 1, ff. 18, Tamiment Library.

${ }^{87}$ Esther Lowell to Harvey and Jessie, 30 January 1933, 18:12, O'Connor Papers, part 2. ${ }^{88}$ Langer, Josephine Herbst, 259.

${ }^{89}$ Doris Fine to Fred Fine, “Sunday evening” [n.d.], 2: [3] '1942 (Jan-Feb),' Fine Papers. ${ }^{90}$ Doris Fine to Fred Fine, "Saturday afternoon” [n.d.], 2: [3] '1942 (Jan-Feb),' Fine Papers.

${ }^{91}$ Joshua Lieberman to Harvey O'Connor, 18 June 1928, 9:5, O'Connor Papers, part 2.

${ }^{92}$ See correspondence between Harvey and Carl and Laura Brannin, 12:6, O'Connor Papers, part 2; Peggy Greenfield to Harvey and Jessie, 23 October 1933, 9:10, O'Connor Papers, part 2.

${ }^{93}$ Len De Caux to Harvey O'Connor, 24 December 1926, 13:6, O'Connor Papers, part 2. ${ }^{94} \mathrm{Abt}$, Advocate and Activist, 180.

${ }^{95}$ Raissa Browder to Earl Browder, 28 December 1941, Series 1:14, Reel 1; Raissia Browder to Earl Browder, 9 April 1942, Series 1:14, Reel 1; Robert (Bob) Minor to Earl Browder, 27 May 1941, Series 1:46, Reel 2; Robert Minor to Earl Browder, 6 September 1941, Series 1:46, Reel 2; Robert Minor to Earl Browder, 27 September 1941, Series 1:46, Reel 2, Earl Browder Papers microfilm edition, Tamiment Library, NYU. 
${ }^{96}$ Shipman, It Had to Be Revolution, 145. On the Dill Pickle Club, see Roger A. Bruns, The Damndest Radical: The Life and World of Ben Reitman, Chicago's Celebrated Social Reformer, Hobo King, and Whorehouse Physician (Urbana 1987), 230-45, and the papers of the club, Newberry Library, Chicago, and Reitman Papers, University of IllinoisChicago.

${ }^{97}$ Mark Litchman to Adele Bennett, 7 March 1924, 1:35, Litchman papers, among other references. See also Colette Hyman, Staging Strikes: Workers'Theatre and the American Labor Movement (Philadelphia 1997); Denning, The Cultural Front, 283-361, among others.

${ }^{98}$ Jessie Lloyd O'Connor to Harvey O'Connor, "mon.a/m/", n.d., 17:5, O’Connor Papers, part 2.

${ }^{99}$ Scales and Nickson, Cause at Heart, 8.

${ }^{100}$ Healey and Isserman, Dorothy Healey Remembers, 67.

${ }^{101}$ Jessie to Harvey, Tuesday 26 July [1929], 17:3, O’Connor Papers, part 2.

${ }^{102}$ Healey and Isserman, Dorothy Healey Remembers, 67.

${ }^{103}$ Ibid.

${ }^{104}$ For a more in-depth discussion, see Kathleen A. Brown and Elizabeth Faue, "Revolutionary Desire: Redefining the Politics of Sexuality among American Radicals, 1919-1945," in Kathleen Kennedy and Sharon Ullman (eds), Sexual Borderlands: Essays in the History of Sexuality, (Columbus, $\mathrm{OH}$ forthcoming).

${ }^{105}$ Note the many examples in Left history, including the marriage between Hutchins Hapgood and Neith Boyce, documented in Ellen Kay Trimberger (ed), Intimate Warriors: Portraits of a Modern Marriage, 1899-1944, Selected Works by Neith Boyce and Hutchins Hapgood, (New York 1991).

${ }^{106}$ Langer, Josephine Herbst, 54.

${ }^{107}$ Shipman, It Had to Be Revolution, 175.

${ }^{108}$ For example, Mark Litchman to Vern Smith, 29 January 1924, 1:35; Mark Litchman to Emanuel Slater, 9 January 1922, 1:33; Mark Litchman, letter fragment, n.d., 2:48, Litchman Papers.

${ }^{109}$ Dennis, Autobiography, 17.

${ }^{110}$ Healey and Isserman, Dorothy Healey Remembers, 30.

"1'Alexandra Kollontai, "Make Way for Winged Eros: A Letter to Working Youth," in Selected Writings of Alexandra Kollontai, trans. with an introduction and commentaries by Alix Holt, (Westport, CT 1977), 276-92, quote from 285.

${ }_{112}$ Thyra Edwards to Philip, 5 Janurary 1934, 1:1, Thyra Edwards Papers, CHS. Edwards was one of the few black women of the Left whose papers are available. She did an international tour of Workers' Education in the 1930s, and wrote on and organized around the Spanish Civil War.

${ }^{113}$ Thyra Edwards to Etha Bell, 14 April 1934, 1:1, Thyra Edwards Papers.

${ }^{114}$ Thyra Edwards to Thelma, 3 November 1939, 1:3, Thyra Edwards Papers.

${ }^{115}$ Shipman, It Had to Be Revolution, 19.

${ }^{116}$ Ibid., 127, 136.

${ }^{117}$ Ibid., 160.

${ }^{118}$ Langer, Josephine Herbst, 121.

119 Josephine Herbst to Katherine Anne Porter, 20 July 1931, Special Collections Division, University of Maryland Libraries, College Park, Maryland, cited in Langer, 120. There is a developing literature on women in the Communist Party and the sexual 
relations of the Left, and we can only touch on it here. For a recent synthesis, see Coiner, Better Red, esp. 39-71; and Kathleen A. Brown, "The 'Savagely Fathered and Unmothered World' of the Communist Party, U.S.A.: Feminism, Maternalism, and 'Mother Bloor," Feminist Studies 25:3 (Fall 1999), 537-70. For last quote, see Coiner, Better Red, 3.

${ }^{120}$ Shipman, It Had to Be Revolution, 80.

${ }^{121}$ Joe Pass to Harvey O'Connor, 24 August 1962, 3:22, O’Connor Papers, part 2. This is not, however, how Mark Litchman told the story.

${ }^{122}$ Shipman, It Had to Be Revolution, 201.

${ }^{123}$ The Liberator was the successor to the radical journal, The Masses, but more explicitly linked to the emerging Communist party. It was published between 1918 and 1924.

${ }^{124}$ Adolf Dehn to Wayne Cooper, 14 January, 1964, quoted in Cooper, Claude McKay, $150-51$.

${ }^{125}$ In Miriam Allen deFord's biography of her husband, Maynard Shipley, she relates stories of Shipley's being propositioned by both correction officers and older boys in the House of Refuge; see Up-Hill All the Way, 27-29. See also Scales and Nickson, Cause at Heart, 46, 65; Richmond, $A$ Long View from the Left, 160; Paul Crouch, 'Southern Radical,' [typewritten manuscript], n.d., circa 1946, Box 17, ff. 'General: Informers: Crouch, Paul, 1946-1951,' in American Committee for Protection of the Foreign Born Records, Labadie Library, University of Michigan Library; Carlos Bulosan, America is in the Heart, (Seattle $1973 \mathrm{c} .1946$ ), 155, among others.

${ }^{126}$ Carroll Smith-Rosenberg, "The New Woman as Androgyne," in Disorderly Conduct: Visions of Gender in Victorian America (New York 1985), 245-96; George Chauncey, Gay New York: Gender, Urban Culture, and the Making of the Gay Male World, 18901940, (New York 1994); idem, "From Sexual Inversion to Homosexuality: Medicine and the Changing Conceptualization of Female Deviance," Salmagundi 58-59 (Fall/Winter 1982-83), 114-46.

${ }^{127}$ Armistead Collier to Miriam Allen deFord, 16 August 1922, 25:5; Armistead to Miriam, 25 November 1925, 25:11, both in Collier Papers. On Carpenter, Ellis, and the new sexology, see Sheila Rowbotham and Jeffrey Weeks, Socialism and the New Life: The Personal and Sexual Politics of Edward Carpenter and Havelock Ellis (London 1977); Mari Jo Buhle, Feminism and Its Discontents: A Century of Struggle with Psychoanalysis (Cambridge, MA 1998).

${ }^{128}$ Armistead Collier to Miriam deFord, 25 September 1925, 25:11; Miriam to Armistead, 22 December 1925, 25:11, both in the Collier Papers.

${ }^{129}$ See Bonnie Haaland, Emma Goldman: Sexuality and the Impurity of the State (Montreal 1994), esp. 123-81. See also Gert Hekma, Harry Oosterhuis, James Steakley, "Leftist Sexual Politics and Homosexuality," Journal of Homosexuality, 29:2/3 (1995), special issue, 'Gay Men and the Sexual History of the Political Left' 1-40; Saskia Poldervaart, "Theories about Sex and Sexuality in Utopian Socialism," ibid., 41-67; Hubert Kennedy, "Johann Baptist von Schweitzer: The Queer Marx Loved to Hate," ibid., 69-96.

${ }^{130}$ Scales and Nickson, Cause at Heart, 223-24.

${ }^{131}$ See Brown and Faue, "Revolutionary Desire."

${ }^{132}$ See Brown, "Ella Reeve Bloor"; idem, "Savagely Fathered and Un-mothered World"; Johanningsmaier, Forging American Communism; James R. Barrett, 'Revolution and Personal Crisis: Communist Politics and Changing Identity in the Life of William $\mathbf{Z}$. 
Social Bonds, Sexual Politics, and Political Community 45

Foster,' unpublished paper, North American Labor History Conference, Wayne State University, 18 October 1996; and his William Z. Foster and the Tragedy of American Communism (Urbana 2000).

${ }^{133}$ See, for instance, Jennie B. Austin to Carl Nold, 13 March, 1932 and Kate Rotchek to Carl Nold, 17 April 1932, Carl Nold Papers, Labadie Collection, University of Michigan. ${ }^{134}$ Emma Goldman, Living My Life, vol.1, reprint, (New York 1970, c. 1931); Lucy Eldine (Gonzalez) Parsons to Carl Nold, 30 May 1932, Nold Papers; Falk, Love, Anarchy and Emma Goldman, chapter 1. 